\title{
PENINGKATAN HASIL BELAJAR SISWA KELAS VI PADA MATA PELAJARAN IPA TENTANG GERHANA BULAN DAN MATAHARI DENGAN MENGGUNAKAN METODE DEMONSTRASI DI SD NEGERI 1 KALIWANGI KECAMATAN PURWOJATI KABUPATEN BANYUMAS TAHUN PELAJARAN 2015/ 2016
}

\author{
Oleh: \\ Marsiyah \\ SD Negeri Kaliwangi Purwojati Banyumas
}

\begin{abstract}
ABSTRAK
Penelitian ini merupakan penelitian tindakan kelas (PTK) yang bertujuan untuk meningkatkan hasil belajar siswa dengan menggunakan metode demonstrasi pada siswa VI SD Negeri 1 Kaliwangi kecamatan Purwojati Kabupaten Banyumas. Penerapn metode demonstrasi dalam kegiatan pembelajaran dimungkinkan dapat meningkatkan hasil belajar siswa pokok bahasan gerhana bulan dan matahari. Untuk mengetahui bagaimana penerapan metode demonstrasi dapat meningkatkan hasil belajar siswa terhadap mata pelajaran IPS kelas VI SD Negeri 1 Kaliwangi. dilaksanakan dua siklus, dengan acuan setiap siklus dilakukan sekali pertemuan pembelajaran. Sedang teknik pengumpulan data dengan pengambilan tes di akhir pembelajaran, serta menganalisis data kuantitatif menggunakan metode analitis deskritif komparatif, dengan membandingkan masing-masing siklus. Subyek penelitian siswa kelas VI SD Negeri 1 Kaliwangi dengan jumlah sebanyak 14 siswa.

Hasil pelaksanaan menunjukkan bahwa dengan penerapan metode demonstrasi, hasil belajar siswa menunjukkan ada kenaikan pada setiap tahapan siklus. Hal tersebut dapat diketahui dari adanya peningkatan dari kondisi awal siswa yang tuntas adalah 57\%, pada saat siklus I menjadi $79 \%$, sedangkan pada siklus II mencapai $86 \%$.
\end{abstract}

Kata kunci: Metode demonstrasi, Hasil belajar IPA

\section{Pendahuluan}

Dalam proses pembelajaran, guru hendaknya memiliki kemampuan untuk dapat tampil di depan kelas menyampaikan materi pelajaran dengan baik supaya tujuan pembelajaran dapat dicapai, tujuannya yaitu meningkatkan hasil belajar siswa. Maka dari itu sebelum proses pembelajaran dimulai guru harus mempersiapkan perlengkapan untuk proses pembelajaran.

Untuk mencapai tujuan pembelajaran yaitu peningkatan hasil pembelajaran banyak factor yang mempengaruhinya. Salah satu faktor yang sangat berpengaruh adalah guru, karena guru adalah figur yang dihormati dan jadikan teladan oleh siswa. Oleh karena itu guru harus dapat meningkatkan kreatifitas dan kemampuan dalam proses pembelajaran di kelas. Setelah melakukan pengamatan di SD Negeri 1 Kaliwangi Kecamatan Purwojati Kabupaten Banyumas didapati suatu fakta yaitu hasil belajar siswa kelas VI rendah pada pelajaran IPA tentang terjadinya gerhana bulan dan matahari. Hal ini disebabkan karena pembelajaran yang 
dilakukan menggunkan metode ceramah yang terkesan monoton dan dinilai membosankan siswa. Rendahnya hasil belajar dapat dilihat dari hasil test pada materi terjadinya gerhana bulan dan matahari dengan nilai tertinggi 90, nilai terendah 30, dan hanya ada 9 dari 36 siswa yang memperoleh nilai sama dengan atau lebih dari Kriteria Ketuntasan Minimal (KKM). KKM IPA kelas VI SD Negeri 1 Kaliwangi Kecamatan Purwojati Kabupaten Banyumas Tahun Pelajaran 2014/2015 telah ditetapkan sebesar 70.

Berdasarkan hasil pengamatan diketahui bahwa rendahnya hasil belajar siswa kelas VI di SD Negeri 1 Kaliwangi Kecamatan Purwojati Kabupaten Banyumas karena metode pembelajaran yang dilakukan tidak membuat siswa aktif dalam kegiatan pembelajaran, pembelajaran yang dilaksanakan membuat siswa bosan karena pembelajaran yang dilakukan dengan metode ceramah. Siswa pun kurang memanfaatkan kesempatan bertanya yang diberikan oleh guru. Peneliti perlu melakukan perbaikan pembelajaran yang dilaksanakan di dalam kelas untuk dapat meningkatkan hasil belajar siswa, karena setiap guru pasti menginginkan hasil belajar siswanya baik dan mencapai KKM.

Berdasarkan uraian tersebut di atas maka dapat disimpulkan bahwa penelitian tindakan kelas mempunyai dua masalah yaitu masalah siswa dan masalah metode pembelajaran guru. Masalah yang berhubungan dengan siswa adalah hasil belajar siswa rendah sedangkan masalah pembelajaran yaitu dalam pembelajaran masih menggunakan metode ceramah dan pemberian tugas. Untuk hasil belajar IPA, peneliti merasa perlu menggunakan metode demonstrasi. Metode demonstrasi adalah metode pembelajaran yang menyajikan suatu proses terjadinya sesuatu objek ataupun peristiwa demonstrasi biasanya memakai objek yang sesungguhnya atau memakai model / alat peraga. Maka metode demonstrasi juga kadang kadang disebut metode mengajar modeling. Maka dari itu penelitian tindakan kelas ini berjudul "Peningkatan Hasil Belajar Siswa Kelas VI Pada Mata Pelajaran IPA tentang Gerhana Bulan dan Matahari dengan Menggunakan Metode Demonstrasi di SD Negeri 1 Kaliwangi Kecamatan Purwojati Kabupaten Banyumas Tahun Pelajaran 2014/2015“.

Selanjutnya rumusan masalah dalam penelitian ini adalah " Apakah melalui metode demonstrasi dapat meningkatkan hasil belajar IPA tentang gerhana bulan dan matahari di kelas VI SD Negeri 1 Kaliwangi Kecamatan Purwojati Kabupaten Banyumas Tahun Pelajaran $2014 / 2015 ?$

Tujuan dalam penelitian ini adalah Untuk mengetahui dampak penggunaan metode demonstrasi terhadap hasil belajar siswa kelas VI SD Negeri 1 Kaliwangi Kecamatan Purwojati Kabupaten Banyumas. 


\section{Kerangka Teori}

Hasil belajar adalah suatu penilaian akhir dari proses dan pengenalan yang telah dilakukan berulang-ulang yang akan tersimpan dalam jangka waktu lama atau bahkan tidak akan hilang selama-lamanya karena hasil belajar turut serta dalam membentuk pribadi individu yang selalu ingin mencapai hasil yang lebih baik lagi sehingga akan merubah cara berpikir serta menghasilkan perilaku kerja yang lebih baik. Pembelajaran adalah proses dimana terjadinya kegiatan belajar yang dalam hal ini terjadi di dalam kelas. Metode pembelajaran demonstrasi adalah pembelajaran dengan menyajikan suatu rangkaian proses peristiwa.

Menurut Roestyah N.K (1991 : 84) terdapat tujuan dari penggunaan metode demonstrasi yaitu "Penggunaan metode demonstrasi menunjang proses interaksi belajar mengajar di kelas karena dapat memusatkan perhatian siswa pada pelajaran, meningkatkan partisipasi aktif siswa untuk mengembangkan kecakapan siswa dan memotivasi siswa untuk belajar lebih giat ". Maka dari itu siswa diharapkan lebih aktif dalam proses pembelajaran dikelas dan lebih memahami materi pelajaran yang disampaikan yang pada akhirnya meningkatkan hasil belajar siswa. Atas dasar pernyataan di atas maka tujuan penggunaan metode demonstrasi adalah untuk menunjang proses pembelajaran menuju sesuatu yang lebih baik seperti perhatian siswa menjadi lebih baik saat pembelajaran berlangsung, siswa menjadi lebih aktif dalam pembelajaran, hasil belajar siswa yang terus meningkat.

\section{Kerangka Berpikir}

Kerangka berfikir dalam penelitian ini sebagaimana di paparkan dalam gambar di bawah ini.

Gambar 1. Kerangka berpikir

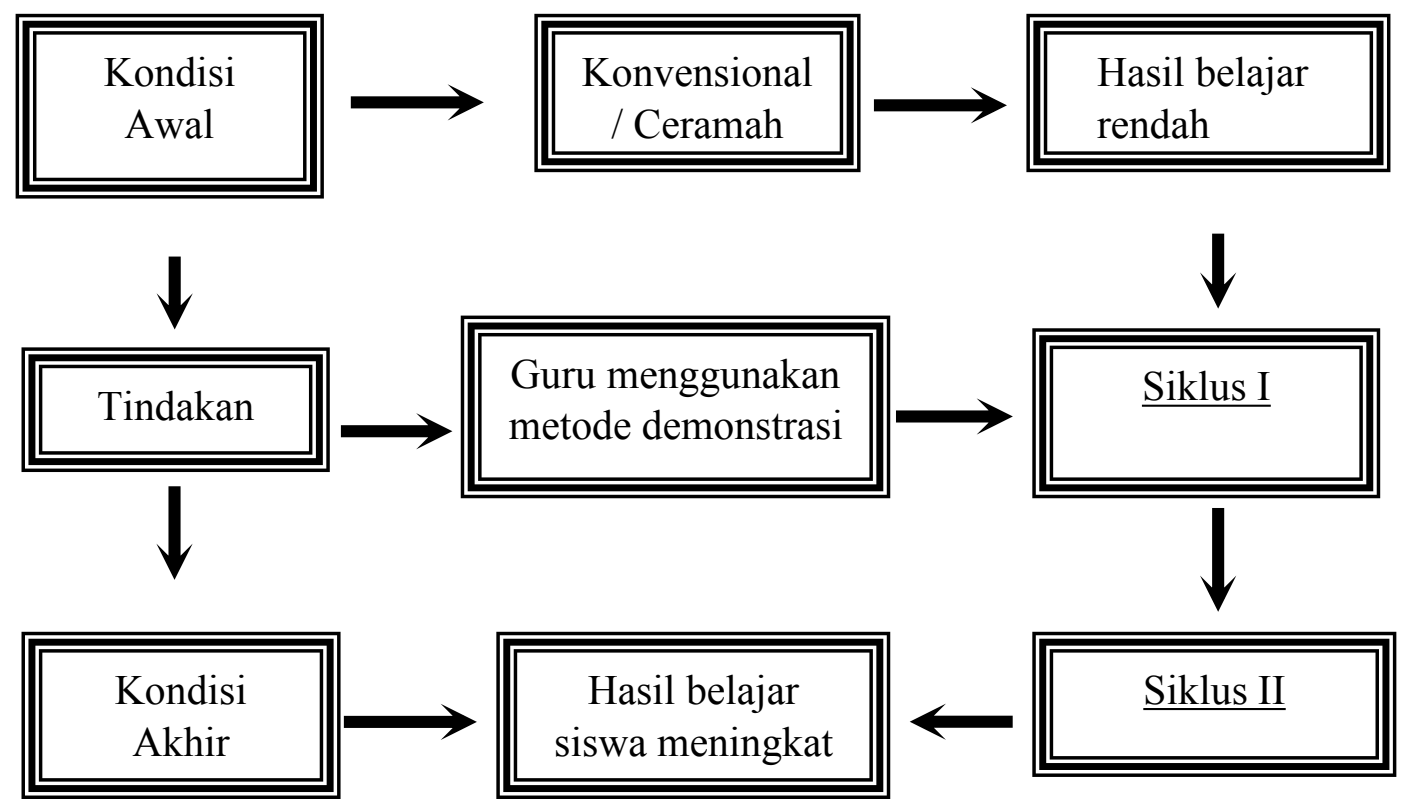




\section{Metode}

Penelitian tindakan kelas ini direncanakan dan dilaksanakan dalam 2 siklus dan masing - masing siklus terdapat 4 tahapan yaitu : Tahap perencanaan; tahap pelaksanaan; tahap evalasi/observasi; tahap refleksi.

\section{Gambar 2. Daur PTK}

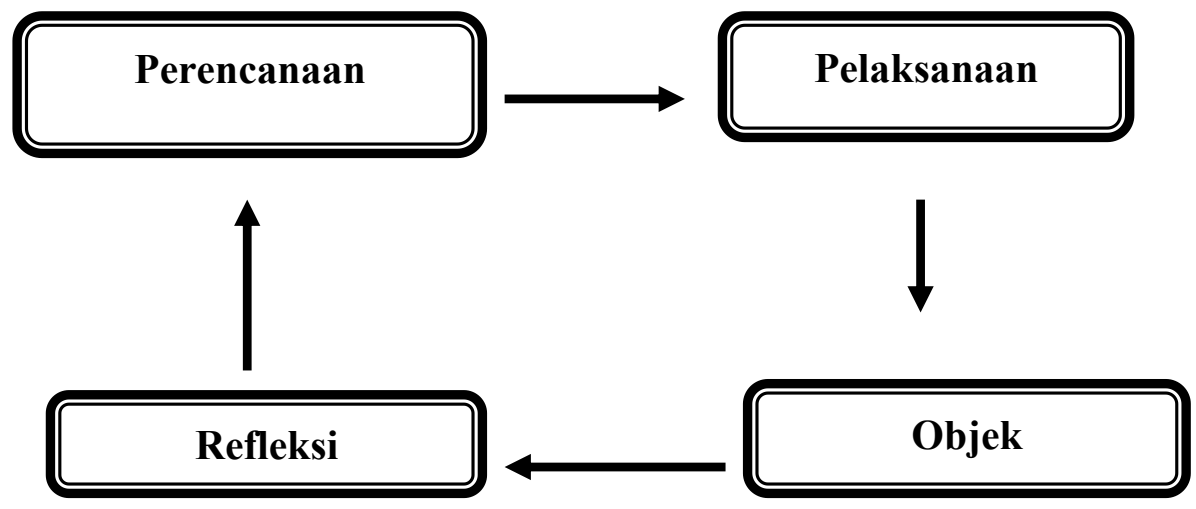

Pada umumnya PTK tidak berjalan 1 kali akan tetapi berjalan pada beberapa siklus seperti gambar di bawah ini :

Gambar 3. Daur Penelitian Tindakan Kelas

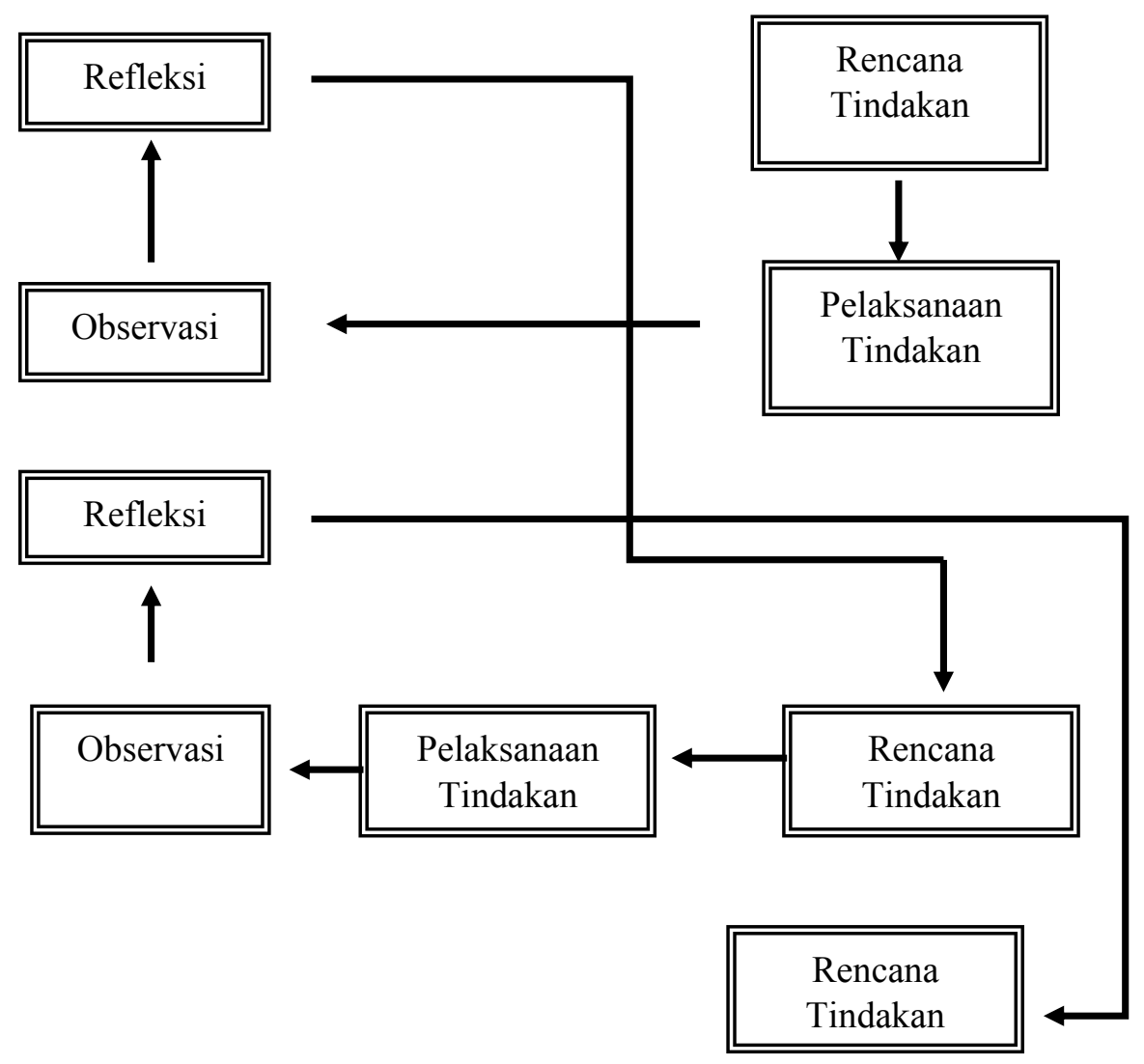




\section{Hasil dan Pembahasan}

Siklus I

Hasil dari pelaksanaan perbaikan pembelajaran pada siklus I mata pelajaran IPA kelas VI SD Negeri Karangtalun Lor hasilnya adalah sebagai berikut :

Tabel 1 Nilai Tes Formatif mata pelajaran IPA pada studi awal dan Siklus I.

\begin{tabular}{|c|c|c|c|c|c|}
\hline \multirow[t]{2}{*}{ No } & \multirow[t]{2}{*}{ Nama Siswa } & \multicolumn{2}{|c|}{ Nilai } & \multicolumn{2}{|c|}{ Kemajuan } \\
\hline & & $\begin{array}{l}\text { Studi } \\
\text { Awal }\end{array}$ & Siklus I & Ada & Tidak \\
\hline 1. & Widodo Kata Saputra & 60 & 70 & $\sqrt{1}$ & - \\
\hline 2 & Rakhmat Sugiarto Saputro & 50 & 50 & - & $\sqrt{ }$ \\
\hline 3 & Anggun Kirana Putri & 70 & 80 & $\sqrt{1}$ & - \\
\hline 4 & Iis Fajriatun & 30 & 40 & $\sqrt{ }$ & - \\
\hline 5 & Kholid Tegar Famuji & 50 & 60 & $\sqrt{ }$ & - \\
\hline 6 & Laila Ayu Rahmadini & 90 & 90 & - & $\sqrt{ }$ \\
\hline 7 & Melani Putri Wulandari & 30 & 50 & $\sqrt{ }$ & - \\
\hline 8 & Abiyanto Setya Martin & 50 & 50 & - & $\sqrt{ }$ \\
\hline 9 & Tina Ade Lusiyanti & 70 & 80 & $\sqrt{ }$ & - \\
\hline 10 & Adilfi Ananda Salimi & 60 & 60 & - & $\sqrt{ }$ \\
\hline 11 & Amelia Eka Rahmawati & 80 & 90 & $\sqrt{ }$ & - \\
\hline 12 & Anggianto Bayu Ardimas & 90 & 100 & $\sqrt{ }$ & - \\
\hline 13 & Dewi Asriati & 60 & 90 & $\sqrt{ }$ & - \\
\hline 14 & Diana Hanifatul Humaeroh & 50 & 50 & - & $\sqrt{ }$ \\
\hline 15 & Eka Rumiyati & 40 & 70 & $\sqrt{ }$ & - \\
\hline 16 & Fajar Hendrianto & 70 & 80 & $\sqrt{ }$ & - \\
\hline 17 & Fandi Nuzzaini & 50 & 80 & $\sqrt{ }$ & - \\
\hline 18 & Heli Tamara & 40 & 80 & $\sqrt{ }$ & - \\
\hline 19 & Ifah Nurul Faida & 80 & 80 & - & $\sqrt{ }$ \\
\hline 20 & Isna Maharani & 60 & 80 & $\sqrt{ }$ & - \\
\hline 21 & Istiana Nurhidayah & 50 & 50 & - & $\sqrt{ }$ \\
\hline 22 & Kurniawan Bagus Wicaksono & 90 & 90 & - & $\sqrt{1}$ \\
\hline 23 & Lisa Cerli Febrianti & 30 & 60 & $\sqrt{ }$ & - \\
\hline 24 & Lutfi Ilham Saputra & 50 & 80 & $\sqrt{ }$ & - \\
\hline 25 & Melan Atmala & 40 & 60 & $\sqrt{ }$ & - \\
\hline 26 & Nur Anas Muzaki & 80 & 80 & - & $\sqrt{ }$ \\
\hline 27 & Nofi Kurnianti & 60 & 60 & - & $\sqrt{ }$ \\
\hline 28 & Purbandaru Prabawansyah & 50 & 80 & $\sqrt{ }$ & - \\
\hline 29 & Putri Humairo & 90 & 90 & - & $\sqrt{ }$ \\
\hline 30 & Resti Marlisyah Putri & 30 & 70 & $\sqrt{ }$ & - \\
\hline 31 & Samroh Septiani & 50 & 50 & - & $\sqrt{ }$ \\
\hline
\end{tabular}




\begin{tabular}{|l|l|c|c|c|c|}
\hline $\mathbf{3 2}$ & Syefani Julia Putri & 40 & 70 & $\sqrt{ }$ & \multicolumn{1}{|c|}{-} \\
\hline $\mathbf{3 3}$ & Setia Triyani & 70 & 70 & - & $\sqrt{ }$ \\
\hline $\mathbf{3 4}$ & Tantri Seviana Setianingrum & 50 & 50 & $\sqrt{ }$ & - \\
\hline $\mathbf{3 5}$ & Umi Solihatun & 50 & 80 & $\sqrt{ }$ & - \\
\hline $\mathbf{3 6}$ & Syeviana Aulia Nur Zahra & 60 & 90 & $\sqrt{ }$ & - \\
\hline Jumlah & $\mathbf{2 0 7 0}$ & $\mathbf{2 5 6 0}$ & & \\
\hline Rata - rata & $\mathbf{5 7 , 5}$ & $\mathbf{7 1 , 1 1}$ & & \\
\hline Tuntas Belajar & $\mathbf{1 1}$ & $\mathbf{2 3}$ & & \\
\hline Tidak Tuntas Belajar & $\mathbf{2 5}$ & $\mathbf{1 3}$ & & \\
\hline Persentase Tuntas Belajar & $\mathbf{3 0 , 5 5 \%}$ & $\mathbf{6 3 , 8 8 \%}$ & & \\
\hline Persentase Tidak Tuntas & $\mathbf{6 9 . 4 5 \%}$ & $\mathbf{3 6 , 1 2 \%}$ & & \\
\hline
\end{tabular}

Berdasarkan tabel 2. dapat dilihat peningkatan perolehan nilai formatif siswa sebagai berikut: Jumlah nilai dari 36 siswa pada studi awal 2070, di siklus I meningkat menjadi 2560. Pada studi awal jumlah nilai rata - rata siswa 57,5 pada siklus I meningkat menjadi 71,11. Jumlah siswa yang tuntas belajar pada studi awal 11 siswa, terjadi peningkatan pada siklus I menjadi 25 siswa. Pada studi awal jumlah siswa yang belum tuntas belajar 23 siswa, pada siklus I menjadi 13 siswa. Siswa yang belum tuntas belajar pada studi awal ada $69,45 \%$ dan pada siklus I hanya $36,12 \%$.

Peneliti mendapatkan data hasil refleksi di dalam pelaksanaan siklus I, yaitu, ketika pembelajaran sedang berlangsung beberapa siswa kurang memperhatikan, ini disebabkan oleh siswa kurang dilibatkan dalam pembelajaran pada siklus I, pembelajaran dengan metode demonstrasi ini masih menitik beratkan kepada guru. Alat peraga yang digunakan belum lengkap dan tidak menarik perhatian siswa, alat peraga yang digunakan berupa globe, bola tenis, bola pingpong, dan senter tidak banyak atau dengan kata lain alat peraga hanya untuk guru saja. Sehingga hanya guru dan perwakilan dari siswa saja yang mendemonstrasikan terjadinya gerhana bulan dan matahari.

Siklus II

Data hasil pelaksanaan perbaikan pembelajaran pada siklus II di SD Negeri Karangtalun Lor Kecamatan Purwojati adalah sebagai berikut: 
Tabel 2. Nilai Tes Formatif mata pelajaran IPA pada SIKLUS I dan Siklus II.

\begin{tabular}{|c|c|c|c|c|c|}
\hline \multirow[t]{2}{*}{ No } & \multirow[t]{2}{*}{ Nama Siswa } & \multicolumn{2}{|c|}{ Nilai } & \multicolumn{2}{|c|}{ Kemajuan } \\
\hline & & Siklus I & Siklus II & Ada & Tidak \\
\hline 1. & Widodo Kata Saputra & 70 & 80 & $\sqrt{ }$ & - \\
\hline 2 & Rakhmat Sugiarto Saputro & 50 & 80 & $\sqrt{ }$ & - \\
\hline 3 & Anggun Kirana Putri & 80 & 80 & - & $\sqrt{ }$ \\
\hline 4 & Iis Fajriatun & 40 & 70 & $\sqrt{ }$ & - \\
\hline 5 & Kholid Tegar Famuji & 60 & 70 & $\sqrt{ }$ & - \\
\hline 6 & Laila Ayu Rahmadini & 90 & 90 & - & $\sqrt{ }$ \\
\hline 7 & Melani Putri Wulandari & 50 & 70 & $\sqrt{ }$ & - \\
\hline 8 & Abiyanto Setya Martin & 50 & 80 & $\sqrt{ }$ & - \\
\hline 9 & Tina Ade Lusiyanti & 80 & 80 & - & $\sqrt{ }$ \\
\hline 10 & Adilfi Ananda Salimi & 60 & 80 & $\sqrt{ }$ & - \\
\hline 11 & Amelia Eka Rahmawati & 90 & 90 & - & $\sqrt{ }$ \\
\hline 12 & Anggianto Bayu Ardimas & 100 & 100 & - & - \\
\hline 13 & Dewi Asriati & 90 & 90 & - & $\sqrt{ }$ \\
\hline 14 & Diana Hanifatul Humaeroh & 50 & 90 & $\sqrt{ }$ & - \\
\hline 15 & Eka Rumiyati & 70 & 70 & - & $\sqrt{ }$ \\
\hline 16 & Fajar Hendrianto & 80 & 80 & - & $\sqrt{ }$ \\
\hline 17 & Fandi Nuzzaini & 80 & 80 & - & $\sqrt{ }$ \\
\hline 18 & Heli Tamara & 80 & 80 & - & $\sqrt{ }$ \\
\hline 19 & Ifah Nurul Faida & 80 & 80 & - & $\sqrt{ }$ \\
\hline 20 & Isna Maharani & 80 & 80 & - & $\sqrt{ }$ \\
\hline 21 & Istiana Nurhidayah & 50 & 70 & $\sqrt{ }$ & - \\
\hline 22 & $\begin{array}{l}\text { Kurniawan Bagus } \\
\text { Wicaksono }\end{array}$ & 90 & 90 & - & $\sqrt{ }$ \\
\hline 23 & Lisa Cerli Febrianti & 60 & 70 & $\sqrt{ }$ & - \\
\hline 24 & Lutfi Ilham Saputra & 80 & 80 & - & $\sqrt{ }$ \\
\hline 25 & Melan Atmala & 60 & 70 & $\sqrt{ }$ & - \\
\hline 26 & Nur Anas Muzaki & 80 & 80 & - & $\sqrt{ }$ \\
\hline 27 & Nofi Kurnianti & 60 & 80 & $\sqrt{ }$ & - \\
\hline 28 & Purbandaru Prabawansyah & 80 & 80 & - & $\sqrt{ }$ \\
\hline 29 & Putri Humairo & 90 & 90 & - & $\sqrt{ }$ \\
\hline 30 & Resti Marlisyah Putri & 70 & 90 & $\sqrt{ }$ & - \\
\hline 31 & Samroh Septiani & 50 & 90 & $\sqrt{ }$ & - \\
\hline 32 & Syefani Julia Putri & 70 & 80 & $\sqrt{ }$ & - \\
\hline 33 & Setia Triyani & 70 & 80 & $\sqrt{ }$ & - \\
\hline 34 & Tantri Seviana Setianingrum & 50 & 90 & $\sqrt{ }$ & - \\
\hline 35 & Umi Solihatun & 80 & 90 & $\sqrt{ }$ & - \\
\hline 36 & Syeviana Aulia Nur Zahra & 90 & 90 & - & $\sqrt{ }$ \\
\hline
\end{tabular}




\begin{tabular}{|l|c|c|l|l|}
\hline Jumlah & $\mathbf{2 5 6 0}$ & $\mathbf{2 9 4 0}$ & & \\
\hline Rata - rata & $\mathbf{7 1 , 1 1}$ & $\mathbf{8 1 , 6 6}$ & & \\
\hline Tuntas Belajar & $\mathbf{2 3}$ & $\mathbf{3 6}$ & & \\
\hline Tidak Tuntas Belajar & $\mathbf{1 3}$ & $\mathbf{0}$ & & \\
\hline Persentase Tuntas Belajar & $\mathbf{6 3 , 8 8 \%}$ & $\mathbf{1 0 0 \%}$ & & \\
\hline Persentase Tidak Tuntas & $\mathbf{3 6 , 1 2 \%}$ & $\mathbf{0 \%}$ & & \\
\hline
\end{tabular}

Dari tabel diatas dapat dinyatakan sebagai berikut Jumlah nilai dari 36 siswa, pada awal pembelajaran adalah 2070 kemudian pada siklus I meningkat menjadi 2560 dan pada siklus II terjadi peningkatan hasil belajar menjadi 2940. Jumlah nilai rata - rata pada pembelajaran awal adalah 57,5 kemudian pada siklus I mengalami peningkatan menjadi 71,11 dan pada siklus II meningkat lagi menjadi 81,66. Pada studi awal siswa yang tuntas belajar sebanyak 11 siswa (30,55\%) kemudian pada siklus I mengalami peningkatan menjadi 23 siswa (63,88\%), dan pada siklus II 100\% tuntas belajar yaitu sebanyak 36 siswa. Pembelajaran awal siswa yang belum tuntas belajar sebanyak 25 siswa $(69,45 \%)$, pada siklus I yang belum tuntas belajar hanya sebanyak 13 siswa $(36,12 \%)$, dan pada siklus II semua tuntas belajar.

Deskripsi Hasil Siklus I hasil pembelajaran studi awal di kelas VI SD Negeri Karangtalun Lor Kecamatan Purwojati Kabupaten Banyumas masih menunjukan hasil belajar yang rendah. Kemudian setelah dilakukan perbaikan pembelajaran pada siklus I, jumlah siswa yang tuntas belajar sebanyak 7 siswa dari 24 siswa (63,64\%), dengan nilai rata - rata 74,55. Rekapitulasi peningkatan hasil belajar siswa pada siklus I dapat dilihat tabel berikut :

Tabel 3. Rekapitulasi Hasil Belajar Siklus I

\begin{tabular}{|c|l|c|c|c|c|}
\hline \multirow{2}{*}{ No } & \multicolumn{2}{|c|}{ Tahap } & \multicolumn{2}{|c|}{ Siswa yang tuntas } & \multicolumn{2}{c|}{ Siswa belum tuntas } \\
\cline { 3 - 6 } & & Frekuensi & Persentase & Frekuensi & Persentase \\
\hline $\mathbf{1}$ & Studi Awal & 11 & $30,55 \%$ & 25 & $69,45 \%$ \\
\hline $\mathbf{2}$ & Siklus I & 23 & $63,88 \%$ & 13 & $36,12 \%$ \\
\hline
\end{tabular}


Gambar 4. Diagram Batang Ketuntasan Hasil Belajar Siswa Siklus I

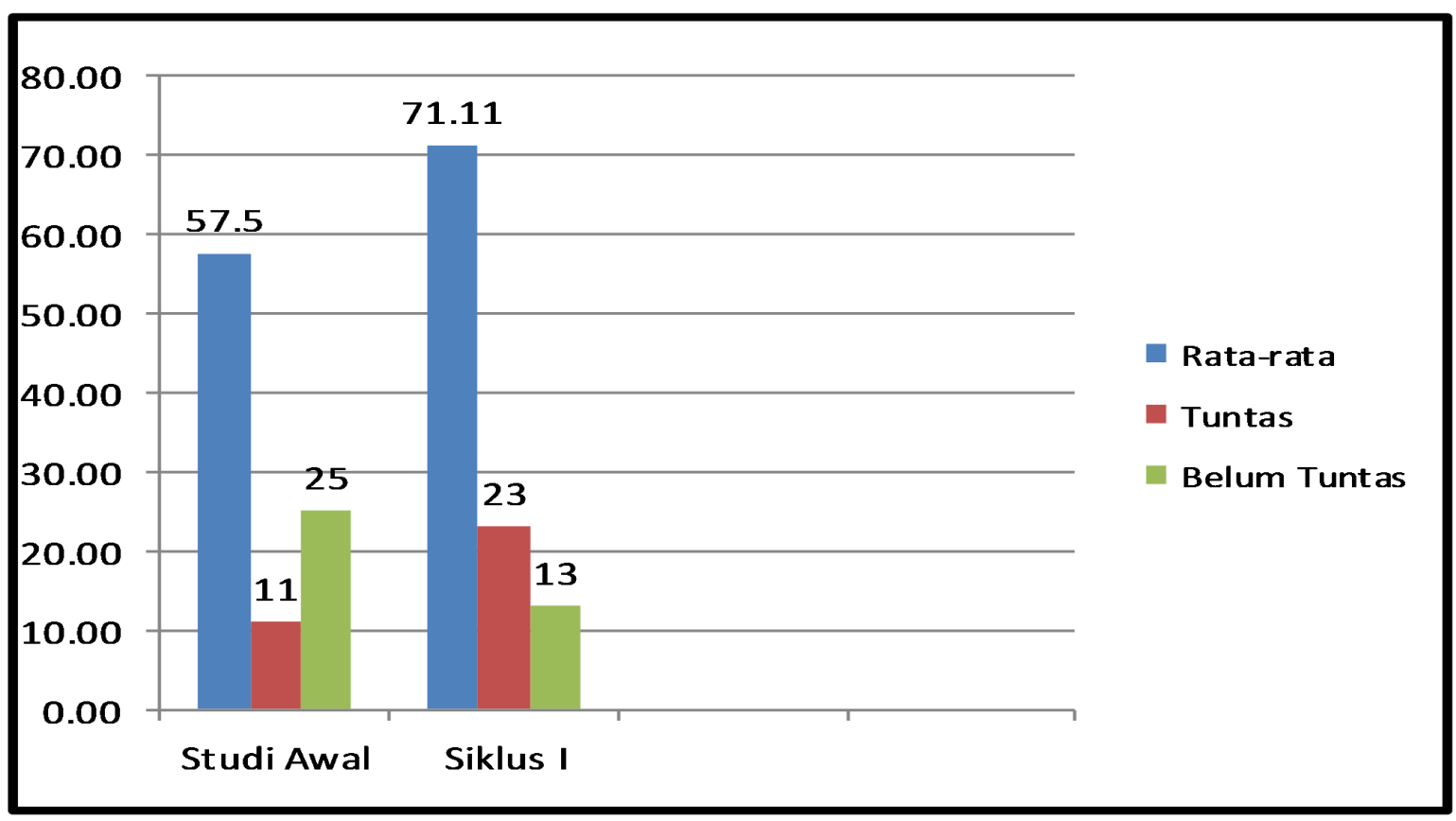

Pada Siklus II hasil pembelajaran di studi awal dan siklus I masih rendah pada mata pelajaran IPA di kelas VI SD Negeri Karangtalun Lor Kecamatan Purwojati Kabupaten Banyumas. Namun setelah dilaksanakannya perbaikan pembelajaran siklus II, semua siswa tuntas belajar yaitu $100 \%$, dengan rata - rata nilai 81,66 . Rekapitulasi peningkatan hasil belajar dapat dilihat ditabel berikut:

Tabel 4. Rekapitulasi Peningkatan Hasil Belajar Siklus II

\begin{tabular}{|c|l|c|c|c|c|}
\hline \multirow{2}{*}{ No } & \multirow{2}{*}{ Tahap } & \multicolumn{2}{c|}{ Siswa yang tuntas } & \multicolumn{2}{c|}{ Siswa belum tuntas } \\
\cline { 3 - 6 } & & Frekuensi & Persentase & Frekuensi & Persentase \\
\hline $\mathbf{1}$ & Studi Awal & 11 & $30,55 \%$ & 25 & $69,45 \%$ \\
\hline $\mathbf{2}$ & Siklus I & 23 & $63,88 \%$ & 13 & $36,12 \%$ \\
\hline $\mathbf{3}$ & Siklus II & 36 & $100 \%$ & 0 & $0 \%$ \\
\hline
\end{tabular}

Gambar 5. Diagram Batang Ketuntasan Hasil Belajar Siswa

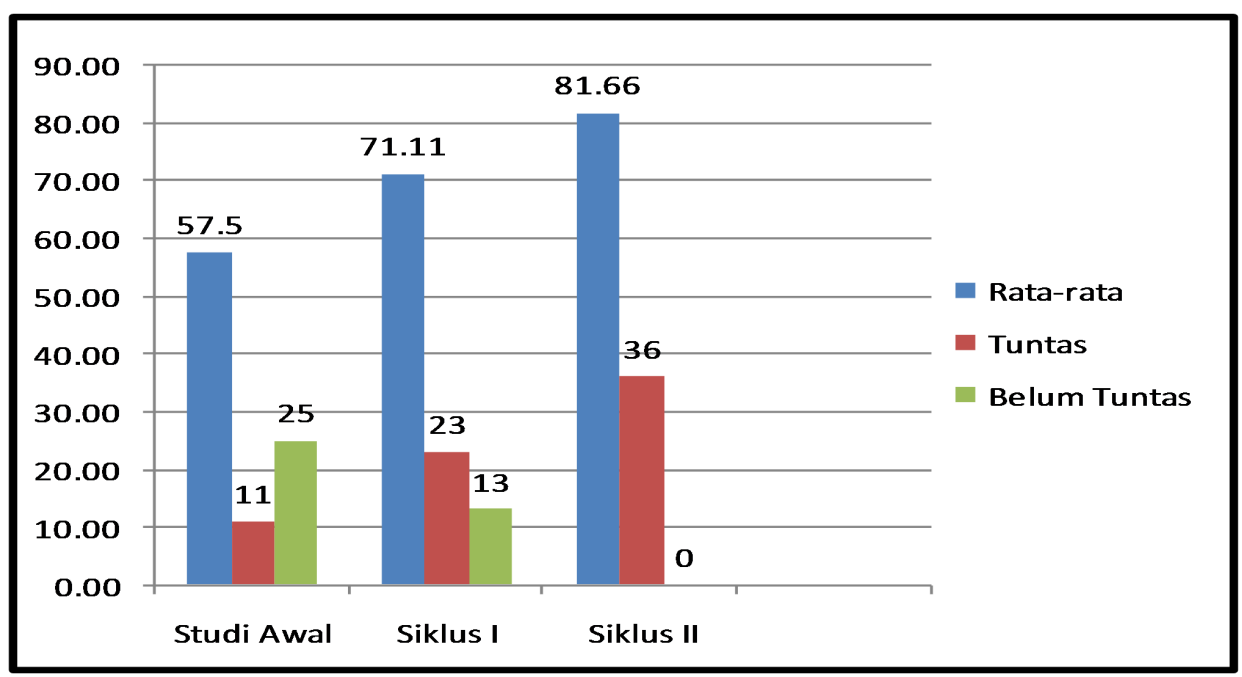




\section{Pembahasan}

Pada siklus I, Permasalahan pada mata pelajaran IPA tentang terjadinya gerhana bulan dan matahari di kelas VI SD Negeri Karangtalun Lor Kecamatan Purwojati Kabupaten Banyumas adalah rendahnya hasil belajar siswa. Hal ini dikarenakan pada saat pembelajaran awal metode pembelajarannya hanya menggunakan ceramah yang membuat siswa terkesan bosan dan tidak tertarik terhadap pembelajaran yang dilaksanakan. Maka dari itu pembelajaran dengan menggunakan metode demonstrasi dilaksanakan pada siklus I yang bertujuan untuk meningkatkan hasil belajar. Alasan metode ini dipilih karena siswa dapat terlibat langsung dalam pembelajaran sehingga siswa dapat memahami, tertarik pada mata pelajaran IPA tentang terjadinya gerhana matahari dan bulan dengan menggunakan alat peraga berupa globe, bola tenis dan bola pingpong yang telah dirangkai menggunakan kawat. Setelah dilaksanakanya perbaikan pembelajaran dengan metode demonstrasi maka terjadi peningkatan hasil belajar siswa, akan tetapi ada beberapa yang belum mencapai KKM. Hal ini disebabkan karena media pembelajaran yang dipakai menarik dan siswa pun kurang terlibat dalam pelaksanaan pembelajaran. Oleh karena itu untuk mengatasi hal ini peneliti mengadakan perbaikan pembelajaran yaitu siklus II. Pada siklus II peneliti berharap hasil belajar siswa lebih meningkat dan mencapai KKM.

Pada siklus II hasil belajar siswa meningkat dengan signifikan sesuai target KKM. Pada prasiklus ketuntasan belajar sebesar 30,55\%, kemudian di siklus I ketuntasan belajar menjadi $63,88 \%$, dan pada siklus II ketuntasan belajar siswa mencapai 100\%, karena pada siklus II penggunaan alat peraga lebih banyak dan menarik, sehingga siswa lebih tertarik dalam pembelajaran IPA tentang terjadinya gerhana matahari dan bulan. Dengan demikian hasil belajar siswa meningkat serta mencapai target KKM.

\section{Simpulan}

Menurut Wardani, dkk (2005: 27) dalam modul Pemantapan Kemampuan Profesional (PKP) Universitas Terbuka mengemukakan bahwa Simpulan merupakan jawaban atas rumusan masalah yang di ajukan dengan mengacu pada hasil penelitian, rumusan simpulan harus singkat padat dan jelas. Berbekal dari pendapat diatas, peneliti mempunyai simpulan bahwa berdasarkan hasil perbaikan pembelajaran melalui Penelitian Tindakan Kelas pada materi mata pelajaran IPA Kelas VI SD Negeri Karangtalun Lor UPK Purwojati Tahun Pelajaran 2014/2015 dapat disimpulkan bahwa dengan menggunakan metode pembelajaran demonstrasi dapat meningkatkan hasil belajar siswa. Hal ini dibuktikan pada kondisi awal 
dari 36 siswa yang tuntas hanya 11 anak atau 30,55\% dan yang belum tuntas ada 25 anak atau $69,45 \%$ dengan rata-rata kelas 57,5 . Kemudian setelah dilakukan perbaikan pembelajaran pada siklus I hasil belajar siswa mengalami peningkatan sebanyak 23 anak atau 63,88\% dan yang belum tuntas berkurang menjadi 13 anak atau 36,12\% dengan rata-rata kelas naik menjadi 71,11. Dengan demikian hasil pada siklus I belum dapat dikatakan tuntas. Oleh karena itu peneliti melanjutkan penelitiannya pada siklus II.

Pada siklus II perbaikan pembelajaran melalui Penelitian Tindakan Kelas di SD Negeri Karangtalun Lor Kelas VI pada mata pelajaran IPA tentang terjadinya gerhana matahari dan bulan dengan menggunakan metode deminstrasi hasil pembelajarnnya telah berhasil. Hal ini terbukti dari hasil belajar pada siklus II telah mencapai presentase ketuntasan belajar 37 siswa atau 100\% yang mendapat nilai diatas KKM. Hal ini terbukti karena pada siklus I siswa yang tuntas belajar baru sebanyak 23 siswa atau 63,88\%. Namun pada siklus II terjadi kenaikan lagi, yaitu siswa yang tuntas belajar sudah mencapai 37 siswa atau $100 \%$ sehingga pembelajaran telah berhasil karena semua siswa telah mencapai KKM. Berdasarkan hasil pada siklus II, maka peneliti menganggap kegiatan perbaikan pembelajaran melalui Penelitian Tindakan Kelas dalam meningkatkan hasil belajar siswa tentang terjadinya gerhana matahari dan bulan sudah berhasil dan dinyatakan berakhir.

\section{Saran}

Penggunaan metode demonstrasi dalam mata pelajaran IPA kelas VI di SD Negeri Karangtalun Lor Kecamatan Purwojati Kabupaten Banyumas dapat meningkatkan hasil belajar siswa sehingga dapat diambil saran sebagai berikut :

1. Bagi Siswa, Siswa harus aktif dalam pembelajaran supaya proses pembelajaran berjalan dengan efektif dan efisien, sehingga hasil belajarnya dapat meningkat.

2. Bagi Guru, Guru yang melaksanakan pembelajaran dengan menggunakan metode demonstrasi harus menetapkan langkah - langkah pembelajaran yang akan dilaksanakan supaya pembelajaran berjalan lancar, mempersiapkan alat peraga yang lengkap dan beragam juga jumlahnya tidak sedikit atau tidak hanya satu supaya siswa dapat mencoba demonstrasi tersebut, menggunakan alat peraga yang menarik supaya siswa tertarik mengikuti pelajaran.

3. Bagi Sekolah, Hasil penelitian ini diharapkan menjadi inspirasi penelitian lainnya dan menumbuhkan inovasi - inovasi baru dalam pembelajaran di sekolah sehingga dapat meningkatkan kualitas siswa, guru, dan akhirnya kualitas sekolah itu sendiri. 


\section{Daftrar Pustaka}

Daryanto. (1998). Kamus Lengkap Bahasa Indonesia. Surabaya: Apolo Lestari.

Slameto. (1995). Belajar dan Faktor-Faktor yang Mempengaruhi. Jakarta: Rineka Cipta.

Gunarsa, Singgih D. (2003). Psikologi Perkembangan. Jakarta: BPK Gunung Mulia.

Walgito, B. (1981). Pengantar Psikologi Umum, diterbitkan oleh Yayasan Penerbitan Fakultas Psikologi UGM, Yogyakarta.

Djalil Aria, dkk. (2011). Pembelajaran Kelas Rangkap. Jakarta: Pusat Penerbit Universitas Terbuka.

Trianto. (2009). Mendesain Model Pembelajaran Inovatif Progresif. Jakarta. Kencana Prenanda Group.

Hatimah Ihat, dkk. (2010). Pembelajaran Berwawasan Kemasyarakatan. Jakarta : Pusat Penerbit Universitas Terbuka.

Poerwadarminta. (1984). Kamus Umum Bahasa Indonesia. Jakarta: Depdiknas.

Taufik, A., dkk. (2011). Pendidikan Anak di Sekolah Dasar, Jakarta: Universitas Terbuka.

Salahuddin, M. (1990). Pengantar Psikologi Pendidikan. Surabaya: Bina Ilmu.

Hamalik, O. (2001), Proses Belajar Mengajar. Bandung: Sinarbaru Algessindo.

TIM-FKIP. (2009). Pemantapan Kemampuan Mengajar (PKM)- PGSD. Jakarta: Pusat Penerbit Universitas Terbuka.

Syah, M. (2008). Psikologi Belajar. Bandung: PT. Remaja Rosdakarya.

Padmono, Y. (1998). Modul Managemen Kelas. Surakarta: FKIP UNS.

Darmansyah. (2006). Psikologi Belajar. Jakarta: Rineka Cipta.

Sapriya. (2009). Pendidikan IPS : Konsep dan Pembelajaran. Bandung: PT. Remaja Rosdakarya.

Samlawi, F., dkk. (1999). Konsep Dasar IPS. Jakarta:Departemen Pendidikan dan Kebudayaan.

Notoatmodjo, S. (2010). Ilmu Perilaku Kesehatan. Jakarta: PT Rineka Cipta

Rivai, Veithzal. \& Sagala, E.J. (2009). Manajemen Sumber Daya Manusia untuk 
Perusahaan. Jakarta: Rajagrafindo Persada.

Bloom, Benyamin. (2011). Strategi Pembelajaran. Jakarta. Pusat Penerbit: Universitas Terbuka.

Brownell,William. (2012). Pendidikan Matematika I. Tangerang Selatan. Penerbit: Universitas Terbuka.

Direktorat Ketenagaan. (2009). Perspektif Pendidikan SD. Jakarta. Penerbit: Universitas Terbuka.

Gagne. (2011). Strategi Pembelajaran. Jakarta. Pusat Penerbit: Universitas Terbuka.

Gestalt. (2011). Strategi Pembelajaran. Jakarta. Pusat Penerbit: Universitas Terbuka.

Joyce, Bruce dan Weil, Marsha (2014). Pembelajaran Kelas Rangkap. Tangerang Selatan. Penerbit: Universitas Terbuka.

R. Hilgard, Ernest. (2011). Strategi Pembelajaran. Jakarta. Pusat Penerbit: Universitas Terbuka.

Romizoswki. (2011). Strategi Pembelajaran. Jakarta. Pusat Penerbit: Universitas Terbuka.

Susilo, Herawati. (2011). Strategi Pembelajaran. Jakarta. Pusat Penerbit: Universitas Terbuka.

Wardani, dkk. (2005). Pemantapan Kemampuan Profesional. Jakarta. Pusat Penerbit: Universitas Terbuka.

Gestalt. (2011) . Modul 2. Pembelajaran Di Sekolah Dasar. Strategi Pembelajaran. Jakarta: Pusat Penerbit Universitas Terbuka.

Brownell, William. (2012). Pendidikan Matematika I. Tangerang Selatan: Penerbit Universitas Terbuka.

R. Hilgard, Ernest. (2011). Modul 2. Pembelajaran Di Sekolah Dasar. Strategi Pembelajaran. Jakarta: Pusat Penerbit Universitas Terbuka.

Crow. (2012). Peningkatan Mutu Dan Minat Belajar IPS Melalui Cooperative Learning Model STAD Di Kelas 7A SMPN 1 Ajibarang. Jurnal Paedagog, 14 (7), hal.4.

Bloom, Benyamin. (2011). Modul 2. Pembelajaran Di Sekolah Dasar. Strategi Pembelajaran. Jakarta: Pusat Penerbit Universitas Terbuka.

Romizoswki. (2011). Modul 2. Pembelajaran Di Sekolah Dasar. Strategi Pembelajaran. Jakarta: Pusat Penerbit Universitas Terbuka.

Direktorat Ketenagaan. (2009). Modul 8. Kurikulum Sekolah Dasar. Perspektif Pendidikan $S D$. Jakart: Penerbit Universitas Terbuka.

Kurikulum 2004. (2012). Modul 2. Pendekatan Dalam Pembelajaran IPA SD: Pembelajaran IPA di SD. Tangerang Selatan: Penerbit Universitas Terbuka. 
TIM-Mills. (2012). (2012). Peningkatan Hasil Belajar IPS Melalui Cooperative Learning Dengan Model STAD Di Kelas IX-B SMPN 2 Kedungbanteng Tahun Pelajaran 2011-2012. Jurnal Paedagog, 15 (7), hal.134.

Joyce, Bruce dan Weil, Marsha.(2014).Pembelajaran Kelas Rangkap. Tangerang Selatan. Penerbit: Universitas Terbuka 